Article

\title{
Investigating the Viability of Epithelial Cells on Polymer Based Thin-Films
}

\author{
Boštjan Vihar ${ }^{1,2, * \mathbb{D}}$, Jan Rožanc ${ }^{1} \mathbb{D}$, Boštjan Krajnc ${ }^{1}$, Lidija Gradišnik ${ }^{1}$, Marko Milojević ${ }^{1}$, Laura Činč Ćurićc ${ }^{1}$ \\ and Uroš Maver ${ }^{1,3}$ (iD
}

1 Faculty of Medicine, Institute of Biomedical Sciences, University of Maribor, Taborska Ulica 8, SI-2000 Maribor, Slovenia; jan.rozanc@um.si (J.R.); bostjan.krajnc@um.si (B.K.); lidija.gradisnik@um.si (L.G.); marko.milojevic1@um.si (M.M.); laura.cinc@um.si (L.Č.Ć.); uros.maver@um.si (U.M.)

2 IRNAS d.o.o, Limbuška Cesta 76b, SI-2000 Maribor, Slovenia

3 Department of Pharmacology, Faculty of Medicine, University of Maribor, Taborska Ulica 8, SI-2000 Maribor, Slovenia

* Correspondence: bostjan.vihar@um.si

check for

updates

Citation: Vihar, B.; Rožanc, J.; Krajnc,

B.; Gradišnik, L.; Milojević, M.; Činč

Ćurić, L.; Maver, U. Investigating the Viability of Epithelial Cells on

Polymer Based Thin-Films. Polymers 2021, 13, 2311. https://doi.org/ $10.3390 /$ polym 13142311

Academic Editors: Ana Vallés-Lluch, Guillermo Vilariño-Feltrer and José Carlos Rodríguez Hernández

Received: 30 June 2021

Accepted: 9 July 2021

Published: 14 July 2021

Publisher's Note: MDPI stays neutral with regard to jurisdictional claims in published maps and institutional affiliations.

Copyright: (c) 2021 by the authors. Licensee MDPI, Basel, Switzerland. This article is an open access article distributed under the terms and conditions of the Creative Commons Attribution (CC BY) license (https:// creativecommons.org/licenses/by/ $4.0 /$ )

\begin{abstract}
The development of novel polymer-based materials opens up possibilities for several novel applications, such as advanced wound dressings, bioinks for 3D biofabrication, drug delivery systems, etc. The aim of this study was to evaluate the viability of vascular and intestinal epithelial cells on different polymers as a selection procedure for more advanced cell-polymer applications. In addition, possible correlations between increased cell viability and material properties were investigated. Twelve polymers were selected, and thin films were prepared by dissolution and spin coating on silicon wafers. The prepared thin films were structurally characterized by Fourier transform infrared spectroscopy, atomic force microscopy, and goniometry. Their biocompatibility was determined using two epithelial cell lines (human umbilical vein endothelial cells and human intestinal epithelial cells), assessing the metabolic activity, cell density, and morphology. The tested cell lines showed different preferences regarding the culture substrate. No clear correlation was found between viability and individual substrate characteristics, suggesting that complex synergistic effects may play an important role in substrate design. These results show that a systematic approach is required to compare the biocompatibility of simple cell culture substrates as well as more complex applications (e.g., bioinks).
\end{abstract}

Keywords: polymers; thin films; viability; morphology; HUVEC; HUIEC

\section{Introduction}

With the advent of tissue engineering and regenerative medicine, tissue-specific decellularized extracellular matrices (dECMs) have emerged as excellent sources for advanced cell culture applications. This can be attributed to their close recapitulation of the biochemical and mechanical properties of the histological microenvironment, which enhances cell viability, maturation, and migration [1-5]. Studies have shown that dECM can also be used as a promising source of (bio)printing inks for 3D bioprinting applications in the production of various tissue types, including adipose, cartilage, muscle, cardiac, and liver tissues [1,6-12]. However, the use of tissue-specific dECMs also has disadvantages. Procurement depends on sacrificial tissues, which are limited in availability and require ethical considerations. In addition, the structure and composition of the starting material may vary from "batch to batch." Finding alternative sources of scaffold materials that are inexpensive, widely available, and adaptable in a composition that adequately mimics the bio-physico-chemical properties of the native ECM would therefore be an important step toward constructing complex tissues and organs. Several material candidates have been successfully used for tissue engineering, and much research has been done on the biocompatibility of materials and their influence on cell growth and development [13-15]. 
Most original research has been performed using individual cell-material combinations with composite materials optimized for printability and executed in 3D cell culture setups [13-15]. Although a large amount of data has been collected and compared in some excellent reviews [13-15], a systematic approach comparing the basic interactions of cells with specific polymers and their properties is currently lacking. Thus, both the correlation and the causal chain between individual substrate characteristics and cellular behavior are poorly understood.

The aim of this study was a preliminary selection process for polymers to reduce the total number of experiments required for scaffold design, which rises exponentially with every additional material. It is clear that respective cell cultures have clear preferences in terms of culture substrate [13-15]; however, the underlying reasons seem to be complex and require further research. Thus, it seems reasonable to reduce the number of polymers at the 2D level before adding new experimental parameters (such as stiffness, porosity, concentration, etc.) at the 3D level. Therefore, in this work, polymer thin films were prepared using materials that have been previously tested for biocompatibility (either in vivo or in vitro) and systematically compared under the same experimental conditions. Twelve polymers were selected, mainly natural, carbohydrate, and protein-based materials, which are briefly described below. Poly(lactide-co-glycolide) (PLGA) [16,17], which does not fall into either category but is frequently used for bioengineering applications (e.g., with fibroblasts, mesenchymal stem cells (MSCs), or cancer cells) [11,18-20], was also examined for comparison. Due to its reversible cross-linking mechanism with divalent cations, alginic acid (ALG) $[21,22]$ has become a very popular polymer for biofabrication and is used in various innovative scaffolding strategies [23-27]. It has found use with several cell-culture applications, including stem cells, chondrocytes, myoblasts, pancreatic islets, etc. [13]. Adding functional groups can also alter cell adhesion and development on ALG substrates $[14,27,28]$. In this work, sulfated alginate (ALG-S) $[21,22,28]$ was used in addition to its conventional counterpart. Cellulose-based scaffolds are often based on decellularized plant material. Such scaffolds have been successfully repopulated with MSCs, endothelial cells, chondrocytes, HeLa cells, etc. [29-31]. Cellulose-derived polymers, such as carboxymethylcellulose (CMC) [32], have also been used in the development of bioinks for applications with keratinocytes, fibroblasts, and endothelial cells [22,33-35]. Pullulan (PUL) [36] is a fungus-derived, biodegradable, and non-immunogenic polysaccharide that is FDA approved for many food and pharmaceutical applications [15,37]. Studies have examined its biocompatibility with various cell types, including MSCs, fibroblasts, endothelial cells, and smooth muscle cells [15]. Pullulan has also been successfully combined with dextran in the production of nanoparticles [38]. The biocompatibility of dextran (DEX) [36,39] has already been studied in vitro on cardiomyocytes, fibroblasts, cancer cells, and in vivo [40,41]. In addition, its derivatives have been shown to have antimicrobial effects on Gram-positive and Gram-negative bacteria and yeasts [42]. Hyaluronic acid (HYA) $[43,44]$ is a highly hydrophilic polysaccharide commonly found in animal connective tissue [14,45]. It has been shown to have good biocompatibility with various cell types, including chondrocytes, fibroblasts, endothelial and embryonic cells, and adult stem cells $[15,45,46]$. Due to its antimicrobial properties, chitosan (CHI) [47-49] derived from chitin has also found widespread use in various biomedical applications, including wound dressings and tissue engineering applications, especially for cartilage or bone regeneration $[48,50,51]$. As one of the main components in animal ECM, collagen (COL) [52-54] is an obvious material for tissue engineering and regenerative applications $[24,55,56]$. Both individually and in combination with other polymers, collagen has been shown to support the growth and development of several cell types, including stem cells, fibroblasts, endothelial cells, astroglia, chondrocytes, etc. $[18,57,58]$ As its derivative, gelatin (GEL) $[54,59,60]$ has also been extensively tested in bioengineering [61]. Its support of successful cell growth has been demonstrated for chondrocytes, fibroblasts, hepatocytes, and human embryonic kidney (HEK) cells $[15,62,63]$. Using gelatin scaffolds with seeded follicles, researchers at Shah's laboratory were able to restore fertility in sterile mice [64]. Another protein 
frequently used in scaffolding is fibrin (FIB-CL) [65], which is naturally produced during blood clotting by an enzymatic polymerization process of fibrinogen (FIB) and thrombin $[66,67]$. It has found applications in the cultivation of endothelial cells, fibroblasts, stem cells, and neural constructs $[13,46]$. The final polymer studied in this work was silk fibroin (SILK)[68], which was extracted from silk fibers in a process developed by Rockwood et al. (2011) [69] and has since found applications in biomedical research, including the cultivation of stem cells and fibroblasts [70-72].

The surface and chemical characteristics of the thin films were analyzed and compared to the viability and morphological development of two human tissue-derived epithelial cell types, namely, human intestinal epithelial cells (HUIEC), previously isolated and characterized by our group [73], and a line of human umbilical vein endothelial cells (HUVEC). The selected cell types, which form simple (single-layer) epithelia with little ECM, were suitable candidates for cultivation on flat, thin-film coated substrates.

\section{Results and Discussion}

\subsection{Thin-Film Preparation and Characterization}

To minimize the number of variables, all experiments in this study were performed on thin films, which provide an elegant platform for evaluating material properties and cell culture experiments. The thin films were prepared by spin coating polymer solutions ( $0.5 \mathrm{wt} . \%$ ) on cleaned, square $1 \mathrm{~cm} \times 1 \mathrm{~cm}$ silicon wafers. The samples were dried at ambient conditions and stored at $4{ }^{\circ} \mathrm{C}$ for a maximum of 1 week before further use. The structure and composition of the thin films were investigated to verify their successful application and to evaluate correlations between cell viability and material properties of the substrates. Due to varying viscosity, adhesion, and cohesion properties of the solutions, it was expected that the thin films applied by spin coating would have different thicknesses for each material. However, the controlled and repeatable rotation ensured high reliability and reproducibility of the coatings, as previously described [22,74], which was necessary for the qualitative and semi-quantitative comparison of the material properties and cell behavior.

\subsection{Attenuated Total Reflectance Fourier Transform Infrared Spectroscopy (FTIR-ATR)}

ATR-FTIR was used to confirm the presence of the individual polymers on the silicon wafers and to compare the spectra of films to the respective raw materials. Due to a strong background signal of the silicon wafers and the thin coating of the films, the measured spectra showed weaker polymer signals than the raw material and a strong peak between 2500 and $1800 \mathrm{~cm}^{-1}$, characteristic of the silicon wafer, which was removed from the final diagram to improve legibility. The corresponding recordings of sample FTIR spectra are shown in Figure 1 (the remaining are in the Supplementary Material, Figure S1), and the characteristic vibrational frequencies are summarized in Table 1 . The signal strengths varied with the materials and likely depended (at least in part) on the thickness of the coating. Protein samples resulted in the strongest signals, which were further observed on PLGA, HYA, and CHI samples. However, even the weakest signals measured (for PUL and DEX) retained some of the characteristic vibrations, confirming the presence of the polymer on the wafer. Of interest is the amide I band measured on the fibrinogen (FIB) and fibrin samples, where a peak shift can be observed (see the Supplementary Material, Figure S1), which is a characteristic phenomenon in fibrin polymerization [65]. Overall, all coatings showed characteristic vibrations, as described in previous studies, with the individual material references listed in Table 1 . These results confirm the successful spin coating of all tested solutions, and all thin layers were further processed and characterized. 

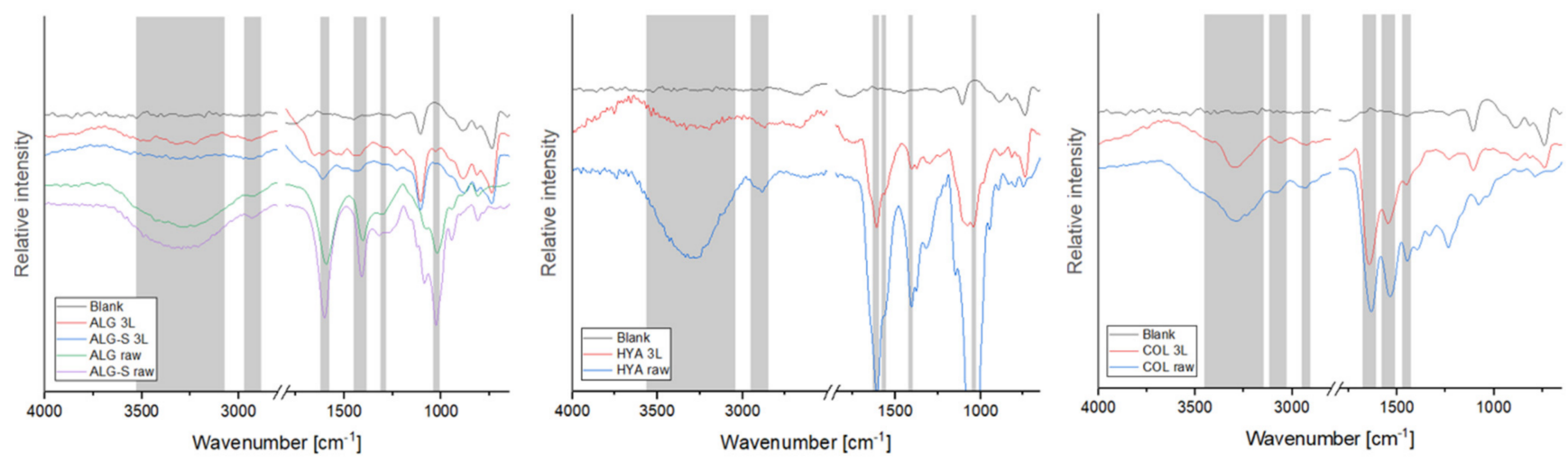

Figure 1. FTIR spectra of ALG, ALG-S, HYA, and COL thin films compared with the spectra of raw polymers and Si wafers. The characteristic bands are marked in grey, with the respective frequencies listed in Table 1 (spectra of the remaining polymers and thin films are available in the Supplementary Material, Figure S1). All carbohydrate samples show characteristic $\mathrm{OH}$ bands at about $3300 \mathrm{~cm}^{-1}$, with additional vibrations for $\mathrm{CH}$ and $\mathrm{CO}$ bonds. In addition, hyaluronic acid and chitosan show $\mathrm{NH}$ and $\mathrm{CN}$ vibrations, which are characteristic for amino groups. The protein samples show peaks for amide I, II, and III at polymer specific frequencies and additional vibrations for $\mathrm{CH}$ and $\mathrm{CO}$ groups. PLGA has a strong and narrow peak at $1750 \mathrm{~cm}^{-1}$, characteristic for its ketone groups, and additional peaks for $\mathrm{CH}$ and $\mathrm{C}-\mathrm{O}$ groups.

Table 1. Characteristic vibration frequencies of polymer thin films measured using ATR-FTIR and compared to data from previous studies.

\begin{tabular}{|c|c|c|c|c|c|c|c|}
\hline Vibration $\left(\mathrm{cm}^{-1}\right)$ & $\begin{array}{c}\text { ALG } \\
{[21,22]}\end{array}$ & $\begin{array}{c}\text { ALG-S } \\
{[21,22]}\end{array}$ & CMC [32] & PUL [36] & DEX $[36,39]$ & HYA $[43,44]$ & $\begin{array}{c}\text { CHI } \\
{[47-49]}\end{array}$ \\
\hline$v(\mathrm{OH})$ & 3300 & 3300 & 3300 & 3330 & 3220 & 3300 & 3300 \\
\hline$v(\mathrm{CH})_{\text {anomer }}$ & 2930 & 2930 & 2930 & 2920 & 2900 & 2925 & \\
\hline$v(\mathrm{COO})_{\text {asym }}$ & 1595 & 1595 & 1595 & & & & \\
\hline$v(\mathrm{COO})_{\text {sym }}$ & 1425 & 1425 & 1415 & & & 1411 & \\
\hline$\delta(\mathrm{CCH})+\delta(\mathrm{OCH})$ & 1300 & 1300 & 1310 & & & & \\
\hline$v(\mathrm{C}-\mathrm{O})$ & 1024 & 1024 & & & & & \\
\hline$v(\mathrm{NH})_{\text {sym }}$ & & & & & & 3300 & 3300 \\
\hline \multirow[t]{2}{*}{ Amide I } & & & & & & 1650 & 1667 \\
\hline & & & & & & 1614 & \\
\hline$v\left(\mathrm{NH}_{2}\right)$ & & & & & & 1560 & 1560 \\
\hline$v(\mathrm{C}-\mathrm{N})$ & & & & & & 1310 & 1309 \\
\hline$v(\mathrm{C}-\mathrm{O}-\mathrm{C})$ & & & & & & 1043 & \\
\hline \multirow[t]{2}{*}{$v(\mathrm{C}-\mathrm{O})$} & & & & 1155 & 1155 & & \\
\hline & & & & 1107 & 1107 & & \\
\hline Vibration $\left(\mathrm{cm}^{-1}\right)$ & $\begin{array}{c}\text { COL } \\
{[52-54]}\end{array}$ & $\begin{array}{c}\text { GEL } \\
{[54,59,60]}\end{array}$ & $\begin{array}{c}\text { GEL-CL } \\
{[54,59,60]}\end{array}$ & FIB [65] & FIB-CL [65] & SILK [68] & $\begin{array}{l}\text { PLGA } \\
{[16,17]}\end{array}$ \\
\hline$v(\mathrm{NH})$ & 3300 & & & & & 3290 & \\
\hline$v(\mathrm{CH})$ & & & & & & 3060 & 3000 \\
\hline Amide $\mathrm{B}$ band & 2928 & 2940 & 2940 & & & 2030 & \\
\hline$v(\mathrm{C}=\mathrm{O})$ & & & & & & & 1750 \\
\hline Amide I & & & & 1700 & & & \\
\hline Amide II & 1544 & 1525 & 1525 & 1520 & 1520 & 1520 & \\
\hline$\delta\left(\mathrm{C}-\mathrm{H}_{2}\right)$ & 1454 & 1450 & 1450 & 1450 & 1450 & 1410 & \\
\hline$\delta\left(\mathrm{C}-\mathrm{H}_{3}\right)$ & 1390 & 1400 & 1400 & 1390 & 1390 & 1380 & \\
\hline Amide III & 1236 & 1235 & 1235 & 1240 & 1240 & 1230 & \\
\hline$v(\mathrm{C}-\mathrm{N})$ & & & & 1300 & 1300 & & \\
\hline$\omega\left(\mathrm{C}-\mathrm{H}_{2}\right)$ & & & & & & 1330 & \\
\hline$v(\mathrm{C}-\mathrm{H})$ methyl & & & & & & & 1450 \\
\hline$v(\mathrm{C}-\mathrm{O}-\mathrm{C})$ & & & & & & 1160 & 1085 \\
\hline$v(\mathrm{C}-\mathrm{O})$ & 1035 & & & & & & \\
\hline
\end{tabular}




\subsection{Atomic Force Microscopy (AFM)}

In order to characterize the surface topology, each thin film was scanned using atomic force microscopy (AFM), which provided roughness parameters and insights into the polymer structure. The results are shown in Figure 2. All recorded samples showed a significant roughness deviation compared to empty silicon wafers ( $0.1 \mathrm{~nm}$ range), which confirms successful coating. In addition to the thin-film roughness, the thickness also appeared to vary. For example, the samples from DEX and PUL showed topographical features visible in the blank samples, whereas they were completely masked in the other samples. Thinner coatings from DEX and PUL were also confirmed by FTIR analysis, as described above. Most of the measured samples showed average roughness values between 0.1 and $1 \mathrm{~nm}$. Thin coatings from COL, HYA, and PLGA showed the highest roughness on the $10 \times 10 \mu \mathrm{m}$ scale (in ascending order). The images of COL, HYA, and PLGA showed the formation of hierarchical structures with higher $\mathrm{Sq}$ and Sa values on the $10 \times 10 \mu \mathrm{m}$ scale, whereas the roughness on the $1 \times 1 \mu \mathrm{m}$ scale remained relatively low. This was particularly evident for PLGA, which showed the formation of dispersed particles with a diameter of 0.5-2 $\mu \mathrm{m}$ and an average height of $160 \mathrm{~nm}$ (Sq) or $137 \mathrm{~nm}$ (Sa). However, individual particles showed a smooth surface with average $\mathrm{Sq}$ and Sa values below $0.2 \mathrm{~nm}$.
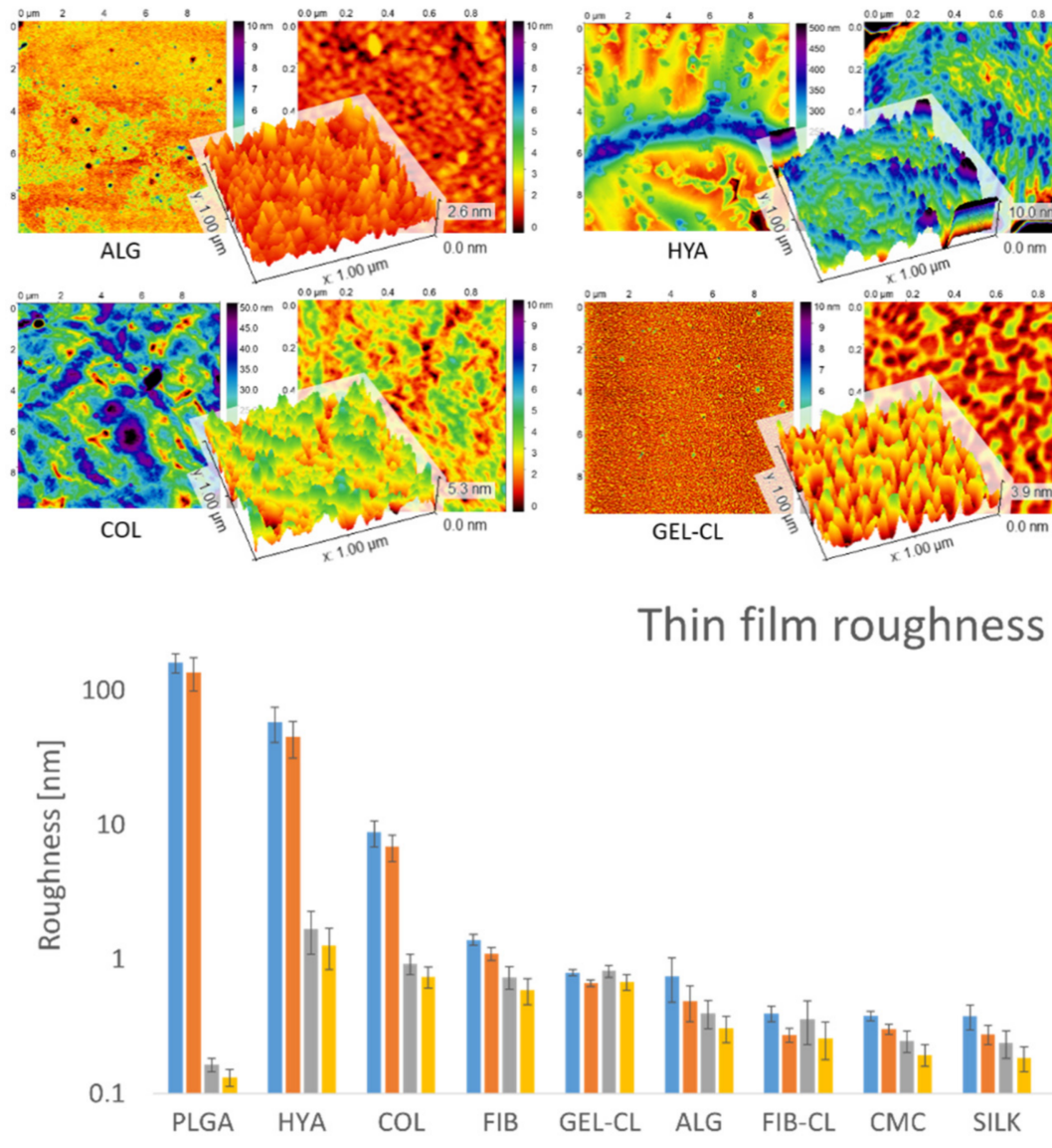

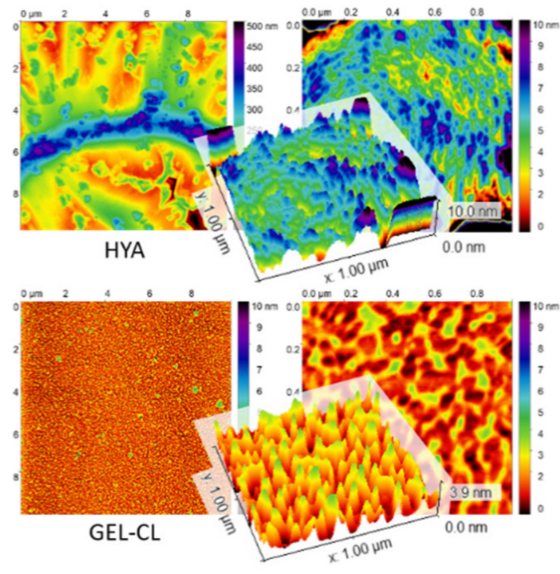

Thin film roughness

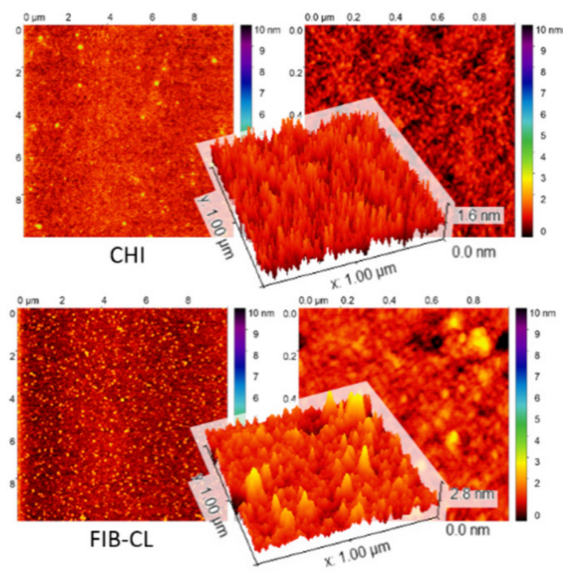

- Sq $10 \mu \mathrm{m}$

- Sa $10 \mu \mathrm{m}$

- Sq $1 \mu \mathrm{m}$

- Sa $1 \mu \mathrm{m}$

Figure 2. Results of AFM analysis. The calculated roughness values (Sq and Sa of $10 \times 10$ and $1 \times 1 \mu \mathrm{m}$ scans) of all prepared thin films are shown in the chart (bottom), as well as micrographs of ALG, HYA, CHI, COL, GEL-CL, and FIB-CL thin films (top - the remaining micrographs are available in the Supplementary Material, Figures S2.1 and S2.2). For each sample, areal scans of $10 \times 10 \mu \mathrm{m}$ (left) and $1 \times 1 \mu \mathrm{m}$ (right) are shown, with a 3D render (middle). The height variation of most polymers lies within the $0-10 \mathrm{~nm}$ range, except for collagen $(0-50 \mathrm{~nm}$ ), and hyaluronic acid and PLGA (in the 0-500 nm range). 


\subsection{Contact Angle Measurement}

The hydrophilicity of thin films was evaluated by measuring static contact angles with ultrapure water, and the results are shown in Figure 3. All coated samples showed absorption of water into the thin film, resulting in gradual flattening of the applied droplets. Therefore, the values shown here reflect the initial contact angles that appeared immediately after application. After treatment with piranha solution, the blank silicon wafers became significantly more hydrophilic [75], as can be seen from the control samples' contact angle measurements $\left(45.9^{\circ}\right)$, which was beneficial for coating distribution. With the exception of HYA and ALG, which further increased the hydrophilicity of base substrates, all other samples showed higher contact angles. However, it is noteworthy that the HYA samples may also have contained salt residues formed during thin-film preparation. Therefore, it was expected that the values of pure HYA be higher. Most thin films had a hydrophilic surface with contact angles between 50 and $70^{\circ}$. The only hydrophobic surface was that of fibrinogen at an average of $105.5^{\circ}$, which was significantly higher than expected [76] and was likely the result of the coating process and resulting roughness, which significantly impacts surface wettability [77].

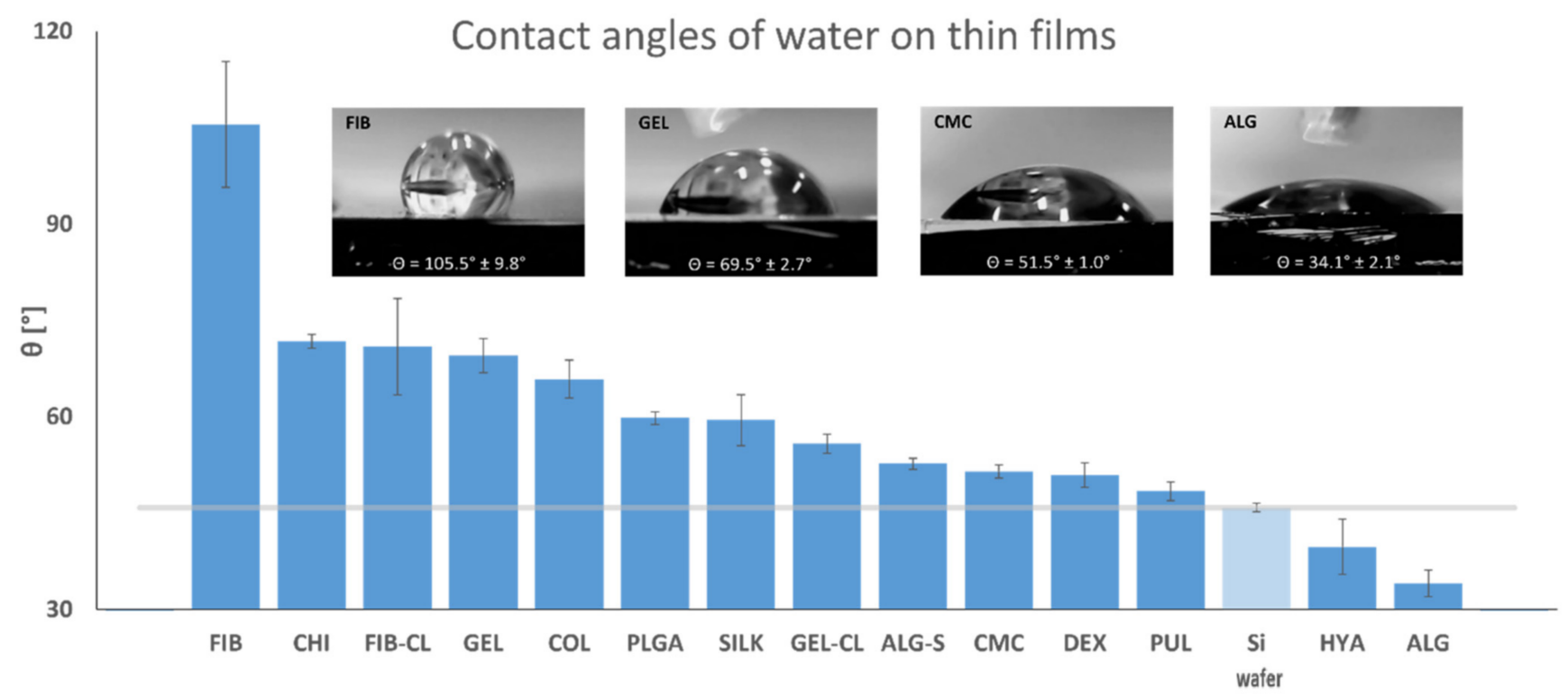

Figure 3. The hydrophilicity of thin films. Static contact angles were determined using the sessile drop method, depositing $1 \mu \mathrm{L}$ droplets of ultrapure water and image capturing after initial contact. The results are summarized in the chart, with the average contact angle of water on clean Si wafers represented by the grey horizontal line. Images of water droplets on FIB, GEL, CMC, and ALG thin films are shown for comparison.

\subsection{Cell Culture and Viability Analysis}

First, the thin films were soaked in the culture medium for $24 \mathrm{~h}$, which was then added to the cell culture in three dilution sets (1:1, 1:2, and 1:4). In addition, the cells were cultured directly on the thin-film surface. Upon contact with the prepared thin films and their extracts, cell viability was assessed by measuring the metabolic activity of the cells using the MTT assay and examining cell morphology by fluorescence staining and subsequent microscopy. In the described experimental design, two main ways in which the polymers could affect the cells must be considered:

- Chemical interactions: The polymers may facilitate or prevent cell attachment, trigger or block membrane receptors, and act as chelators for nutrients or toxic compounds. For example, $\mathrm{CHI}$ is generally considered biodegradable and biocompatible with simultaneous antimicrobial activity, typically attributed to free amino groups $[51,78]$. 
- Structural interactions: Surface roughness and solubility of the polymers determine the attachment surface and its stability and change in viscosity of the culture medium near the thin-film surface.

- Depending on the solubility of the thin films in the nutrient medium under cell culture conditions $\left(37^{\circ} \mathrm{C}, 5 \% \mathrm{CO}_{2}\right)$, the cell-polymer interaction may vary. For soluble thin films, the effect on cell viability should be comparable for direct contact and exposure to extracts, with a correlation between metabolic activity and polymer concentration. For poorly soluble polymers, thin-film extracts are expected to have less effect on cell viability. It is important to note that surface properties such as roughness can only affect the cells if the polymer is poorly soluble and therefore sufficiently stable. In addition to the thin-film properties measured in this study, the available literature was analyzed to compare the influence of thin film on cell development with functional groups of the polymers with which they might interact. Specifically, the polymers were analyzed for hydroxy, carboxyl, or amino groups. The polysaccharides selected for this study consist of repeating hexoses with respective functional groups so that their number per molecular weight could be easily derived from the chemical structure of the individual polymers, as found in the literature $[27,28,35,37,42,45,51]$. The same method of assessing the functional groups per unit molecular weight was also used for PLGA [20]. With their complex amino acid sequences and folding and intertwining chains, the free functional groups of proteins are more difficult to estimate. Therefore, in the work presented here, the number of functional groups was estimated from the proportion of individual amino acids and their functional groups in the total composition alone. E.g., for silk fibroin, which is produced by the silk moth (Bombyx mori), the composition was estimated according to the genetic sequence, coding for $45.9 \%$ glycine, $30.3 \%$ alanine, $12.1 \%$ serine, $5.3 \%$ tyrosine, and $1.8 \%$ valine [ 72 ]. The same procedure was used to determine the amount of functional groups in COL [56], GEL [61], and FIB [66]. For the reasons mentioned above, the number of functional target groups per $100 \mathrm{kDa}$ in proteins is only a rough estimate. It does not necessarily represent the actual value of the functional groups available for interaction with cultured cells.

\subsubsection{HUVEC}

The results of the biocompatibility analysis of prepared thin films and HUVEC cells are shown in Figure 4 (with additional information in the Supplementary Material, Figure S3). The results of the viability analysis (obtained with the MTT test and fluorescence microscopy, shown on the left $\mathrm{Y}$-axis) are plotted against the thin-film characterization data (shown on the right Y-axis) as described in Section 2. Results and Discussion. Most tested materials showed good biocompatibility with the cells. The highest relative viability values at attachment were measured on PLGA substrates with almost double the metabolic activity and cell count compared to the bare $\mathrm{Si}$ wafer. High values were also observed on collagen, fibrin, hyaluronic acid, and gelatin substrates in descending order. The lowest viability was again observed when the cells were cultivated on chitosan substrates, and poor biocompatibility with HUVECs can also be attributed to alginate. The remaining thin films showed the growth and viability of cells similar to the control sample.

\subsubsection{HUIEC}

Cells cultured on collagen showed the highest metabolic activity, cell density, and cell size of all samples (data in the Supplementary Material, Figure S4). The latter was also the only substrate that seemed to be more effective for culturing than the control sample. The other materials resulted in lower viability than the $\mathrm{Si}$ wafers, but to a relatively small extent. Viability was in the range of $80-100 \%$, which may be suitable for certain cell culture applications. The only sample that prevented normal cell development was chitosan, with very few cells observed, which also retained a small and circular shape as a sign of poor adhesion. An estimated biocompatibility score (described further in Section 3. 
Materials and Methods) was attributed to the materials for both cell lines and compared to the thin-film characteristics (see Figure 5). The purpose of the score was to improve the legibility of the data and allow an evaluation of how individual properties impact viability. A non-parametric Spearman's test was performed to statistically analyze possible correlations between thin-film characteristics and individual viability values (MTT results for attachment, extracts, cell number, and cell sizes, respectively).
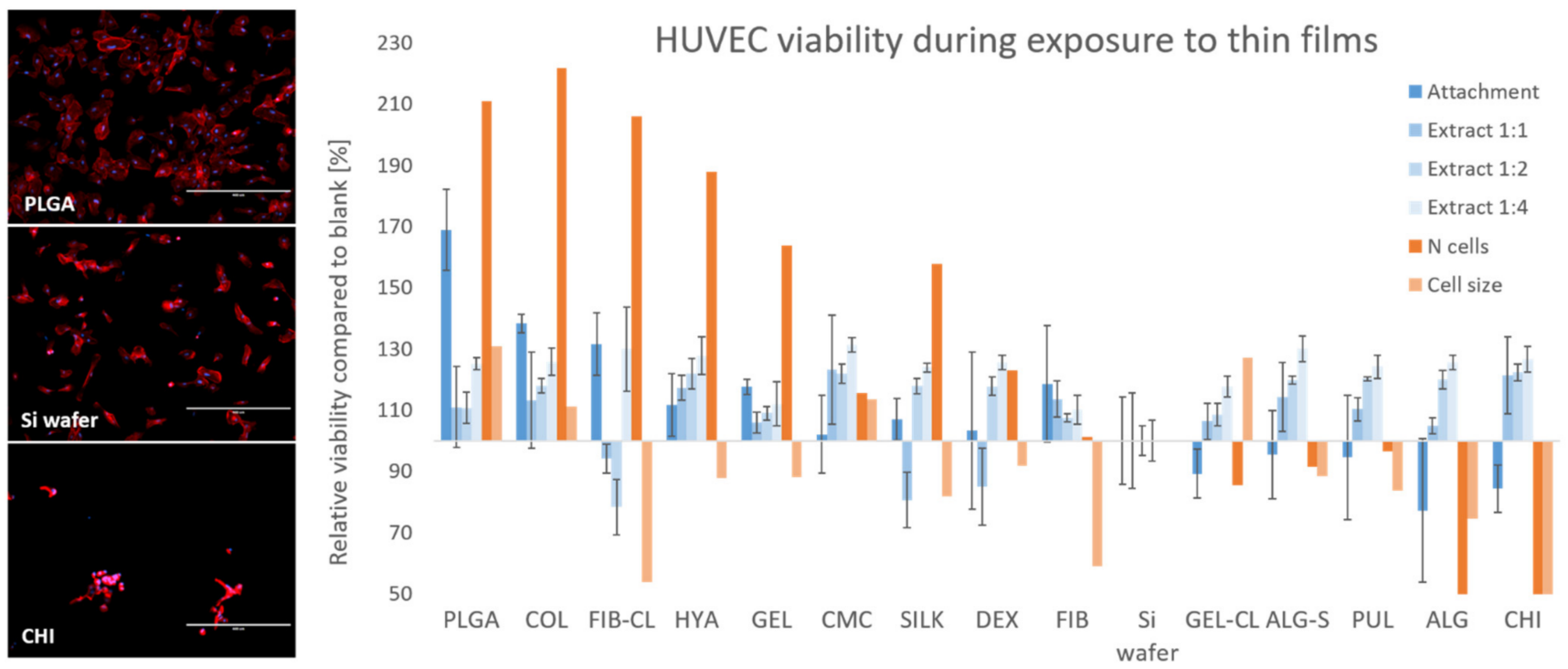

Figure 4. Biocompatibility of the thin films to HUVEC cell culture. Images of HUVEC cells grown on thin films of PLGA, $\mathrm{CHI}$, and the control sample are shown, stained with DAPI and Phalloidin (left). Scale bars indicate a length of $400 \mu \mathrm{m}$. The results of the MTT assay (blue), as well as the evaluation of the morphological analysis (orange), are summarized in the chart (right). The bars represent the relative values compared to the control sample $(100 \%)$. Cells grown on PLGA thin films demonstrated the highest metabolic activity in the MTT assay, as well as high cell density and cell size.
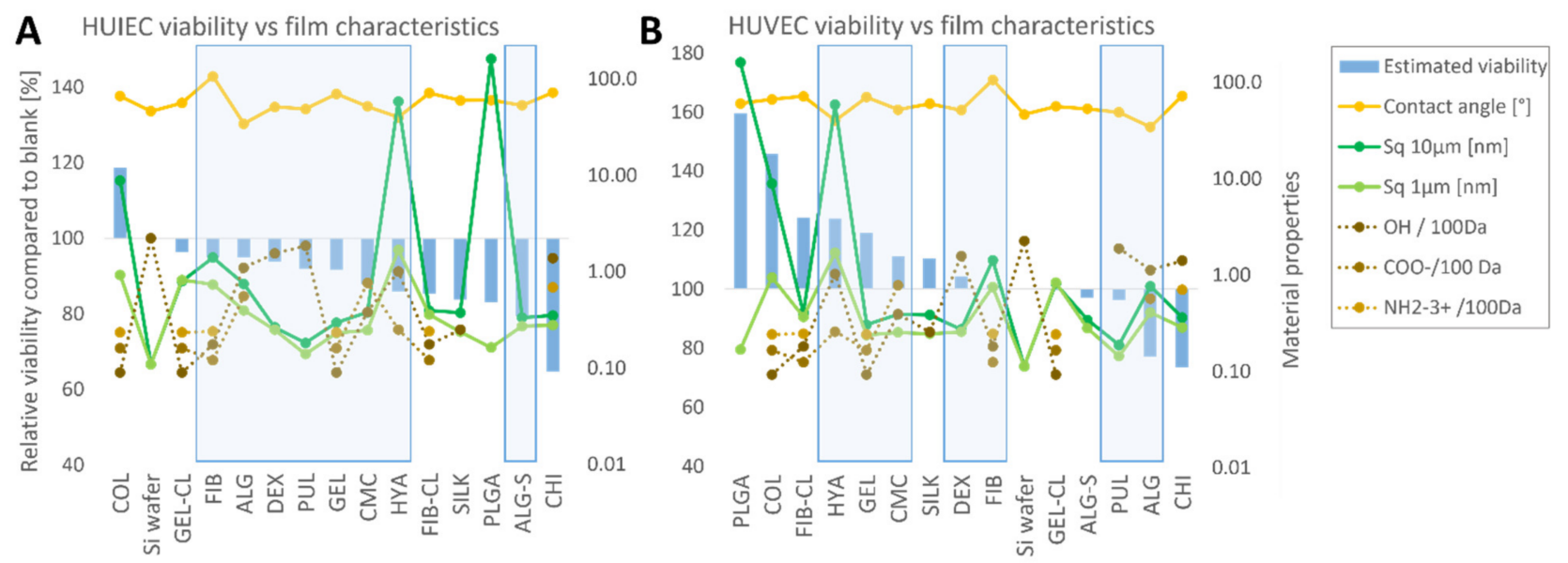

Figure 5. Estimated viability of HUIEC (A) and HUVEC (B) cells compared to thin-film characteristics. For improved legibility of the data, the values of the estimated viability were calculated by combining the results of the MTT assay and cell morphology into a biocompatibility score as shown in Figure 4 and further described in the Materials and Methods section. The estimated viability values are compared to thin-film characteristics (curves plotted against the secondary $Y$ axis). The static water contact angle (yellow), roughness (green), and the number of functional groups (brown) are shown. Water-soluble polymers are marked with a blue frame. 


\subsection{Interpretation of the Results}

COL seemed to be a very suitable material for both cell lines, which is not surprising given its general presence in extracellular matrices and in line with previous studies that showed successful cultivation of vascular and intestinal epithelium on collagen-based substrates [79-81]. For vascular endothelial cells, the highest biocompatibility was attributed to PLGA, which has also been used in vascular tissue engineering and stent fabrication $[20,82]$. The material that proved unsuitable for both cell lines was CHI. Although it had already been used in bioengineering and was considered biocompatible, $\mathrm{CHI}$ nanoparticles also proved to be cytotoxic to liver cells [83]. Surprisingly, the MTT results using CHI extracts showed a positive effect on cell viability. The material is poorly soluble at neutral and high $\mathrm{pH}$, suggesting that either very small amounts of $\mathrm{CHI}$ could be beneficial or that this polymer chelates compounds that would otherwise slow down cells' metabolic activity. Most other materials seemed to be suitable as culture substrates for both cell types. A more extensive quantitative study will be necessary to show how a change in the amount of material available for interaction with the cell culture will affect growth and development. However, the polymer concentrations used in this study to produce thin films were already lower than those typically used in hydrogels for scaffolding and tissue engineering.

Although both cell lines tested showed clear and specific preferences regarding the growth substrate, no direct correlation between biocompatibility and individual material properties that might influence the interaction could be established. This suggests that synergistic effects between substrate properties are likely to play an important role in the development of tissue engineering scaffolds or advanced wound-healing materials. Furthermore, since the materials tend to change their structural properties when immersed from a dry environment at room temperature into a culture medium at $37^{\circ} \mathrm{C}$, it is difficult to predict suitable substrates based on the available data alone. Variable cell-type preferences for specific growth substrates refute the possibility of developing universal "bioinks" with optimal biocompatibility for 3D bioprinting and tissue engineering [84,85]. On the other hand, this presents an opportunity to control the development of individual cell lines within co-cultures or 3D environments that are closer in structure and biochemical cues to their native tissue environment. The empirical determination of cell growth and viability also seems feasible when using the experimental setup described above. It suggests developing a "biocompatibility roadmap" for cell-substrate combinations that will provide researchers and engineers with a tool for material selection and bioink design. In addition, the improvement of cultivation substrates could significantly reduce the time and costs for general cell culture work and, with the advent of cellular agriculture, the agri-food sector as well.

For the successful development of a biocompatibility roadmap, several unanswered questions need to be addressed. These include the characterization of thin films under cell culture conditions and, in particular, the cell-material interface with a focus on binding sites, substrate stability, and possible substrate modifications that allow stable attachment while permitting cell mobility. To better understand cell-material interactions, a more quantitative approach to culturing will likely be required, experimenting with different cell-seeding densities and over longer culturing periods. A live cell-imaging system that provides continuous insight into the culture during incubation would greatly benefit this effort while reducing the number of parallel experiments required for individual time points. Furthermore, additional experiments should be performed on thicker polymer substrates to significantly increase the influence of substrate rheology on the overall interaction. Such experiments can be performed both as a flat monolayer (2D) on thick polymer deposits or their hydrogels and encapsulated in the material (3D).

\section{Materials and Methods}

\subsection{Thin-Film Preparation}

As the substrate for the thin films, silicon wafers (Topsil, Frederikssund, Denmark) were used, which were cut into square $1 \mathrm{~cm}^{2}$ pieces and cleaned thoroughly, as validated 
previously $[33,86]$. Each piece was rinsed with $70 \%$ ethanol and subsequently with ultrapure $\left(18.2 \mathrm{~m} \Omega \mathrm{cm}\right.$ at $\left.25^{\circ} \mathrm{C}\right)$ water. After rinsing, each silicon sample was soaked in piranha solution $\left(\mathrm{H}_{2} \mathrm{O}_{2}(30 \%)\right.$ and $\mathrm{H}_{2} \mathrm{SO}_{4}$ (concentrated) combined in a mixture of $\left.1: 7 \mathrm{v} / \mathrm{v}\right)$ for $15 \mathrm{~min}$ at room temperature, followed by rinsing with and soaking in ultra-pure water for an additional $15 \mathrm{~min}$. Finally, each sample was dried in a stream of dry, high purity N2 ( $99.99 \%$, Messer, Maribor, Slovenia). A total of $0.5 \%$ aqueous solution of the selected natural polymers was prepared according to manufacturer specifications, with certain described exceptions, summarized in Table 2. All chemicals were obtained from Sigma-Aldrich unless otherwise specified. To prepare the polymer thin films, the solutions were spin coated onto cleaned silicon wafers. A layer of polymer solution was deposited by carefully applying $50 \mu \mathrm{L}$ on a fixated wafer and rotating the sample at $2500 \mathrm{RPM}$ for $180 \mathrm{~s}$ using the SPIN-150i-NPP spin coater (SPS Vertriebs GmbH, Berlin, Germany). The process was repeated three times. Afterward, the samples were stored at $4{ }^{\circ} \mathrm{C}$ before further use. Thin films for gelatin and fibrinogen were prepared in duplicate, with one series undergoing cross-linking to produce more stable coatings. Gelatin cross-linking was performed as described previously [64]. Briefly, the samples were soaked in an aqueous solution of $15 \mathrm{mM}$ $\mathrm{N}$-(3-Dimethylaminopropyl)- $\mathrm{N}^{\prime}$-ethylcarbodiimide and $6 \mathrm{mM} \mathrm{N}$-Hydroxysuccinimide for $30 \mathrm{~min}$ at room temperature, followed by careful rinsing using ultrapure $\mathrm{dH}_{2} \mathrm{O}$ and air drying at room temperature overnight. To cross-link fibrinogen and form fibrin, the silicon wafers with thin films were soaked in a $20 \mathrm{mM} \mathrm{CaCl}_{2}$ solution with $1 \mathrm{U} / \mathrm{mL}$ of thrombin for $30 \mathrm{~min}$ at room temperature. Subsequently, the samples underwent careful rinsing using ultrapure water.

Table 2. A summary of the materials used and prepared solutions.

\begin{tabular}{|c|c|}
\hline Polymer & Recipe \\
\hline ALG & $\begin{array}{l}\text { A total of } 0.01 \mathrm{~g} \text { was dissolved in } 2 \mathrm{~mL} \text { of high-purity } \mathrm{dH}_{2} \mathrm{O} \text { with agitation on a } \\
\text { magnetic stirrer at room temperature until completely dissolved. }\end{array}$ \\
\hline ALG-S & $\begin{array}{l}\text { A total of } 0.01 \mathrm{~g} \text { of dry material obtained from Zenobi Group (ETH Zürich, } \\
\text { Switzerland) [28] was dissolved in } 2 \mathrm{~mL} \text { of high-purity } \mathrm{dH}_{2} \mathrm{O} \text { with agitation on a } \\
\text { magnetic stirrer at room temperature until completely dissolved. }\end{array}$ \\
\hline $\mathrm{CMC}$ & $\begin{array}{l}\text { A total of } 0.01 \mathrm{~g} \text { was dissolved in } 2 \mathrm{~mL} \text { of high-purity } \mathrm{dH}_{2} \mathrm{O} \text { with agitation on a } \\
\text { magnetic stirrer at room temperature until completely dissolved. }\end{array}$ \\
\hline PUL & $\begin{array}{l}\text { A total of } 0.01 \mathrm{~g} \text { was dissolved in } 2 \mathrm{~mL} \text { of high-purity } \mathrm{dH}_{2} \mathrm{O} \text { with agitation on a } \\
\text { magnetic stirrer at room temperature until completely dissolved. }\end{array}$ \\
\hline DEX & $\begin{array}{l}\text { A total of } 0.01 \mathrm{~g} \text { was dissolved in } 2 \mathrm{~mL} \text { of high-purity } \mathrm{dH}_{2} \mathrm{O} \text { with agitation on a } \\
\text { magnetic stirrer at room temperature until completely dissolved. }\end{array}$ \\
\hline HYA & $\begin{array}{l}\text { A total of } 0.01 \mathrm{~g} \text { was dissolved in } 2 \mathrm{~mL} \text { of phosphate buffered saline (PBS) with } \\
\text { agitation on a magnetic stirrer at } 90-95^{\circ} \mathrm{C} \text { until completely dissolved, followed } \\
\text { by cooling to } 37^{\circ} \mathrm{C} \text {. }\end{array}$ \\
\hline $\mathrm{CHI}$ & $\begin{array}{l}\text { A total of } 0.01 \mathrm{~g} \text { was dissolved in } 2 \mathrm{~mL} \text { of } 17 \mathrm{mM} \text { solution of acetic acid with } \\
\text { agitation on a magnetic stirrer at room temperature until completely dissolved. }\end{array}$ \\
\hline GEL & $\begin{array}{l}\text { A total of } 0.01 \mathrm{~g} \text { was dissolved in } 2 \mathrm{~mL} \text { of high-purity } \mathrm{dH}_{2} \mathrm{O} \text { with agitation on a } \\
\text { magnetic stirrer at } 40^{\circ} \mathrm{C} \text { until completely dissolved and cooled to room } \\
\text { temperature. }\end{array}$ \\
\hline COL & $\begin{array}{l}\text { A total of } 0.01 \mathrm{~g} \text { was dissolved in } 2 \mathrm{~mL} \text { of } 0.2 \mathrm{M} \text { acetic acid with agitation on a } \\
\text { magnetic stirrer at } 45^{\circ} \mathrm{C} \text { overnight. }\end{array}$ \\
\hline FIB & $\begin{array}{l}\text { A total of } 0.01 \mathrm{~g} \text { was dissolved in } 2 \mathrm{~mL} \text { of } 0.9 \% \mathrm{NaCl} \text { with agitation on a } \\
\text { magnetic stirrer at room temperature until completely dissolved. }\end{array}$ \\
\hline SILK & $\begin{array}{l}\text { A prepared solution was obtained from the department of nanostructured } \\
\text { materials (IJS, Ljubljana, Slovenia) and prepared as previously described }[69,70] \text {. }\end{array}$ \\
\hline PLGA & $\begin{array}{l}\text { A total of } 0.01 \mathrm{~g} \text { was dissolved in } 2 \mathrm{~mL} \text { of acetone with gentle manual agitation } \\
\text { until completely dissolved. }\end{array}$ \\
\hline
\end{tabular}




\subsection{Attenuated Total Reflectance (ATR) FTIR}

To confirm polymer presence on the wafers and their chemical characteristics, Fouriertransform infrared (FTIR) spectra were recorded by measuring the attenuated total reflection (ATR) using a Cary 630 FTIR spectrometer (Agilent, Santa Clara, CA, USA). A spectral range between 4000 and $650 \mathrm{~cm}^{-1}$ (with a resolution of $2 \mathrm{~cm}^{-1}$ ) was recorded for each sample, as described previously [48,86-89].

\subsection{Atomic Force Microscopy (AFM)}

Atomic force microscopy (AFM) was used to evaluate surface topology and surface roughness parameters of the samples using a Keysight 7500 AFM (Keysight Technologies, Santa Rosa, ON, Canada) as described before $[33,48,86,88,89]$. Images were recorded in tapping mode with silicon-based tips (ATEC-NC-20, Nanosensors, Neuchatel, Switzerland). Each sample was scanned at room temperature using a resonance frequency of $210-490 \mathrm{kHz}$ and a force constant of 12-110 N/m. Images in $1024 \times 1024$ pixel resolution were recorded on areas of $10 \times 10$ and $1 \times 1 \mu \mathrm{m}^{2}$. The surface was scanned at 3 locations on the sample to verify the obtained data's consistency. The images were further processed using Gwyddion 2.55 software to calculate the roughness values according to ISO 25178, namely, the root mean square height $(\mathrm{Sq})$ and the arithmetical mean height (Sa) values and visualization of the sample topographies.

\subsection{Contact Angle Measurements}

To determine the samples' hydrophilicity, the static contact angles were measured using the sessile drop technique, whereby ultrapure water was applied to the thin films using a custom-made goniometric setup. Five $1 \mu \mathrm{L}$ droplets per thin film were applied and measured at room temperature and $30 \%$ relative humidity. The entire application process was recorded on video, and the images selected for contact angle calculation were taken immediately after drop deposition. The static contact angles were then evaluated by measuring the enveloping rectangle with ImageJ and the height-width method.

\subsection{Cell Selection and Culturing}

Two lines of epithelial cells were examined in this work, namely, human intestinal epithelial cells (HUIEC) that were previously isolated and characterized by our group [73] and a line of human umbilical vein endothelial cells (HUVEC) purchased from ATTC. A base culture of cells was maintained in Advanced Dulbecco's Modified Eagle's Medium (ADMEM, Gibco, Thermo Scientific, Waltham, MA, USA), supplemented with $5 \%$ (wt) fetal bovine serum (FBS, Gibco, Thermo Scientific, Waltham, MA, USA) at $37^{\circ} \mathrm{C}$ and $5 \% \mathrm{CO}_{2}$.

\subsection{MTT (3-(4,5-Dimethylthiazol-2-yl)-2,5-diphenyltetrazolium Bromide) Test}

Cell viability was determined using the MTT assay $24 \mathrm{~h}$ after contact with the polymers. Metabolically active cells reduce the yellow-colored 3-[4,5-dimethylthiazol-2-yl]-2,5 diphenyltetrazolium bromide (MTT) into formazan. The latter forms purple crystals, soluble in organic solvents such as dimethyl sulfoxide (DMSO). Since formazan's photometric absorption (at $570 \mathrm{~nm}$ ) shows a linear correlation with the overall cell viability, the assay allows for accurate quantification [90-92]. The assay was performed as described previously $[48,86,89]$, with specific details below.

\subsection{Cell Culture with Thin-Film Extracts}

In the first part of the biocompatibility assessment, the extract or elusion test was carried out $[48,86,89]$. The thin films coated with biomaterials were sterilized under UVC irradiation for $30 \mathrm{~min}$ and soaked in $1.5 \mathrm{~mL}$ of ADMEM supplemented with $5 \%$.(wt) FBS and incubated for $24 \mathrm{~h}$ at $37^{\circ} \mathrm{C}$ and $5 \% \mathrm{CO}_{2}$. In parallel, HUVEC and HUIEC cells were seeded into P96 microtiter plates at a concentration of 10,000 cells/well and allowed to attach for $24 \mathrm{~h}$. Next, the extracts' serial dilutions were prepared in the ratios of 1:1,1:2, and $1: 4$ and transferred onto the cell layer, followed by incubation at $37^{\circ} \mathrm{C}$ and $5 \mathrm{wt} . \% \mathrm{CO} 2$ for 
$24 \mathrm{~h}$. Each combination was carried out in four replicates, and additional control samples were prepared, with cells incubated in ADMEM supplemented with $5 \mathrm{wt}$ \% FBS. Following incubation, cell viability was determined using the MTT assay as described above. The medium was removed, and the MTT reagent $(10 \mu \mathrm{L}$ MTT $+90 \mu \mathrm{L}$ medium $)$ was added to the wells and incubated for 2-4 h. After incubation, the MTT reagent was removed, and $100 \mu \mathrm{L}$ of DMSO was added to each well. After $5 \mathrm{~min}$, the crystals had dissolved, and the absorbance was measured at $570 \mathrm{~nm}$ using a Varioskan Flash multi-well plate reader (Thermo Scientific, Waltham, MA, USA).

\subsection{Cell Culture on Thin Films}

Cell viability was also determined when in direct contact with the thin films. The silicon wafer-thin film samples were placed in P24 microtiter plates and sterilized by UVC irradiation for $30 \mathrm{~min}$. Following sterilization, HUVEC and HUIEC cells were seeded on the thin films at a concentration of 50,000 cells/well in $1 \mathrm{~mL}$ of ADMEM supplemented with $5 \%$ FBS. Each experimental condition was tested in three replicates, and a non-coated silicon wafer was used as a control. The samples were incubated for $48 \mathrm{~h}$ at $37^{\circ} \mathrm{C}$ and $5 \%$ $\mathrm{CO}_{2}$, followed by a viability analysis using an MTT test. After incubation, the silicon wafer plates with cells were transferred to a new P24 well plate containing MTT reagent (50 $\mu \mathrm{L}$ $\mathrm{MTT}+450 \mu \mathrm{L}$ medium). After $2-4 \mathrm{~h}$ the MTT reagent was removed, and crystals were dissolved in $250 \mu \mathrm{L}$ of DMSO. A total of $200 \mu \mathrm{L}$ of each sample was then pipetted onto a P96 plate, and the absorbance was measured at $570 \mathrm{~nm}$ using a Varioskan Flash multi-well plate reader (Thermo Scientific, Waltham, MA, USA).

\subsection{Cell Morphology Analysis}

To assess the cell adhesion and morphology of the cells growing on the thin films, phalloidin and DAPI staining were used to visualize the actin filaments and cell nucleus, respectively. The same experimental conditions were applied as for the cell viability testing. After $48 \mathrm{~h}$ of incubation on the thin films, the medium was removed and the cells were incubated for $15 \mathrm{~min}$ at room temperature with a fixing solution (Sigma-Aldrich). Fixation was followed by washing with PBS $(3 \times 15 \mathrm{~min})$ and subsequent staining using CytoPainter Phalloidin-iFlour 555 (1:1000 in PBS with 1\% BSA) for $90 \mathrm{~min}$ at room temperature in total darkness. Before imaging, the staining solution was removed and the samples were covered with a drop of mounting medium (Fluoroshield containing DAPI, Sigma-Aldrich, Burlington, VT, USA) and incubated for $5 \mathrm{~min}$ in total darkness. Imaging was performed using the EVOS cell-imaging system.

\subsection{Statistical Analysis}

Statistical analysis was performed using SPPS Statistics 25 (IBM Corp., Armonk, NY, USA). Normality distribution was determined using the Kolmogorov-Smirnov test and range of skewness and kurtosis. None of the dependent variables were normally distributed and are therefore presented as median and 95\% confidence interval. For statistical analysis, the non-parametric Spearman's test was chosen to test the correlation between dependent and independent variables. $p$-values $<0.05$ were considered statistically significant. All statistical data is available in the Supplementary Material in Figures S5 and S6 and Tables S1.1-1.7 and S2.1-2.7

\subsection{Biocompatibility Score}

For all MTT test results, as well as cell size and cell number (evaluated using ImageJ), the relative values were calculated, and thus the control sample, taking a value of $1(100 \%)$. The obtained values were then corrected with respective weighing factors to account for the differences in environmental impact on the cells. Finally, the total score was determined by the sum of all weighed values, according to Equation (1):

$$
S=4 a+b+0.5 c+0.25 d+2 e+2 f .
$$


Equation (1): Calculating the biocompatibility score (S), where $a$ equals MTT results of cells grown on thin films, $\boldsymbol{b}$ equals MTT results of 1:1 extracts, $\boldsymbol{c}$ equals 1:2 extracts, $\boldsymbol{d}$ equals 1:4 extracts, $e$ equals the relative number of cells observed in the morphological analysis, and $f$ equals the relative cell size.

\section{Conclusions}

This study highlights the specific interaction between vascular and intestinal epithelial cells with different substrates. The results show that the respective cells have clear preferences in regard to growth substrate; however, the growth and development of one cell line do not necessarily provide insight into another cell line's potential behavior on the same set of substrates.

Therefore, the need for a systematic approach to substrate selection for both basic and advanced cell culture applications is becoming increasingly clear. In the transition from traditional to three-dimensional cell culture, this aspect will be crucial in designing and developing tissue-engineering scaffolds, wound-healing materials, drug-delivery systems, and other biomedical applications. However, as the set of possible experiments rises exponentially with every subsequent material-property combination, it seems feasible to narrow the substrate selection for testing on flat surfaces before continuing to the third dimension. Building on the established framework, a roadmap for cell-material interaction can be developed, providing guidelines for selecting components in coatings, scaffold design, and other biomedical applications.

Supplementary Materials: The following are available online at https:/ /www.mdpi.com/article/ 10.3390/polym13142311/s1, Figure S1: FTIR spectra of prepared thin films. Figure S2: AFM scans. Figure S3: HUVEC cell culture images-ranked. Figure S4: HUIEC cell culture images—ranked. Figure S5: Spearman's nonparametric test results: HUVEC—-thin films. Figure S6: Spearman's nonparametric test results: HUIEC — thin films. Table S1: Spearman's nonparametric test of HUVEC viability and polymer characteristics. Table S2: Spearman's nonparametric test of HUIEC viability and polymer characteristics.

Author Contributions: Conceptualization, B.V., J.R., and U.M.; funding acquisition, U.M.; investigation, B.V., J.R., B.K., L.G., M.M., and L.Č.Ć.; methodology, J.R., B.K., L.G., M.M., and L.Č.Ć.; supervision, U.M.; visualization, B.V.; writing-original draft, B.V.; writing—review and editing, B.V. and U.M. All authors have read and agreed to the published version of the manuscript.

Funding: Financial support for this project was provided by the Slovene Ministry of Science, Education, and Sport through grants 5442-1/2018/59 and 5442-1/2018/60. The authors further acknowledge the financial support for this study from the Slovenian Research Agency (grant numbers P-0036, I0-0029, J3-1762, J1-2470 and J1-9169) and through the Young Researcher Programme.

Institutional Review Board Statement: Not applicable.

Informed Consent Statement: Not applicable.

Acknowledgments: Silk fibroin was kindly provided by the research group of Saša Novak, Department for Nanostructured Materials, Jožef Stefan Institute, Ljubljana, Slovenia. Sulfated alginate was kindly provided by the research group of Marcy Zenobi-Wong, Institute of Biomechanics, ETH Zürich, Zürich, Switzerland.

Conflicts of Interest: The authors declare no conflict of interest.

\section{References}

1. Gao, G.; Lee, J.H.; Jang, J.; Lee, D.H.; Kong, J.-S.; Kim, B.S.; Choi, Y.-J.; Jang, W.B.; Hong, Y.J.; Kwon, S.-M.; et al. Tissue Engineered Bio-Blood-Vessels Constructed Using a Tissue-Specific Bioink and 3D Coaxial Cell Printing Technique: A Novel Therapy for Ischemic Disease. Adv. Funct. Mater. 2017, 27. [CrossRef]

2. Ott, H.C.; Matthiesen, T.S.; Goh, S.K.; Black, L.D.; Kren, S.M.; Netoff, T.I.; Taylor, D.A. Perfusion-decellularized matrix: Using nature's platform to engineer a bioartificial heart. Nat. Med. 2008, 14, 213-221. [CrossRef] [PubMed]

3. Gilbert, T.W.; Sellaro, T.L.; Badylak, S.F. Decellularization of tissues and organs. Biomaterials 2006, 27, 3675-3683. [CrossRef] [PubMed] 
4. Kundu, J.; Michaelson, A.; Talbot, K.; Baranov, P.; Young, M.J.; Carrier, R.L. Decellularized retinal matrix: Natural platforms for human retinal progenitor cell culture. Acta Biomater. 2016, 31, 61-70. [CrossRef] [PubMed]

5. Tan, Q.W.; Zhang, Y.; Luo, J.C.; Zhang, D.; Xiong, B.J.; Yang, J.Q.; Xie, H.Q.; Lv, Q. Hydrogel derived from decellularized porcine adipose tissue as a promising biomaterial for soft tissue augmentation. J. Biomed. Mater. Res. A 2017, 105, 1756-1764. [CrossRef]

6. Noor, N.; Shapira, A.; Edri, R.; Gal, I.; Wertheim, L.; Dvir, T. 3D Printing of Personalized Thick and Perfusable Cardiac Patches and Hearts. Adv. Sci. 2019, 6, 1900344. [CrossRef]

7. Pati, F.; Ha, D.H.; Jang, J.; Han, H.H.; Rhie, J.W.; Cho, D.W. Biomimetic 3D tissue printing for soft tissue regeneration. Biomaterials 2015, 62, 164-175. [CrossRef]

8. Jang, J.; Park, H.J.; Kim, S.W.; Kim, H.; Park, J.Y.; Na, S.J.; Kim, H.J.; Park, M.N.; Choi, S.H.; Park, S.H.; et al. 3D printed complex tissue construct using stem cell-laden decellularized extracellular matrix bioinks for cardiac repair. Biomaterials 2017, 112, 264-274. [CrossRef]

9. Pati, F.; Jang, J.; Ha, D.H.; Won Kim, S.; Rhie, J.W.; Shim, J.H.; Kim, D.H.; Cho, D.W. Printing three-dimensional tissue analogues with decellularized extracellular matrix bioink. Nat. Commun. 2014, 5, 3935. [CrossRef]

10. Jang, J.; Kim, T.G.; Kim, B.S.; Kim, S.W.; Kwon, S.M.; Cho, D.W. Tailoring mechanical properties of decellularized extracellular matrix bioink by vitamin B2-induced photo-crosslinking. Acta Biomater. 2016, 33, 88-95. [CrossRef]

11. Pati, F.; Song, T.H.; Rijal, G.; Jang, J.; Kim, S.W.; Cho, D.W. Ornamenting 3D printed scaffolds with cell-laid extracellular matrix for bone tissue regeneration. Biomaterials 2015, 37, 230-241. [CrossRef]

12. Lee, H.; Han, W.; Kim, H.; Ha, D.H.; Jang, J.; Kim, B.S.; Cho, D.W. Development of Liver Decellularized Extracellular Matrix Bioink for Three-Dimensional Cell Printing-Based Liver Tissue Engineering. Biomacromolecules 2017, 18, 1229-1237. [CrossRef]

13. Hospodiuk, M.; Dey, M.; Sosnoski, D.; Ozbolat, I.T. The bioink: A comprehensive review on bioprintable materials. Biotechnol. Adv. 2017, 35, 217-239. [CrossRef]

14. Ng, W.L.; Chua, C.K.; Shen, Y.-F. Print Me An Organ! Why We Are Not There Yet. Prog. Polym. Sci. 2019, 97. [CrossRef]

15. Naahidi, S.; Jafari, M.; Logan, M.; Wang, Y.; Yuan, Y.; Bae, H.; Dixon, B.; Chen, P. Biocompatibility of hydrogel-based scaffolds for tissue engineering applications. Biotechnol. Adv. 2017, 35, 530-544. [CrossRef]

16. Paragkumar, N.T.; Edith, D.; Six, J.-L. Surface characteristics of PLA and PLGA films. Appl. Surf. Sci. 2006, 253, 2758-2764. [CrossRef]

17. Okassa, L.N.; Marchais, H.; Douziech-Eyrolles, L.; Herve, K.; Cohen-Jonathan, S.; Munnier, E.; Souce, M.; Linassier, C.; Dubois, P.; Chourpa, I. Optimization of iron oxide nanoparticles encapsulation within poly(d,l-lactide-co-glycolide) sub-micron particles. Eur. J. Pharm. Biopharm. 2007, 67, 31-38. [CrossRef]

18. Chen, G.; Sato, T.; Ohgushi, H.; Ushida, T.; Tateishi, T.; Tanaka, J. Culturing of skin fibroblasts in a thin PLGA-collagen hybrid mesh. Biomaterials 2005, 26, 2559-2566. [CrossRef]

19. Zamani, F.; Amani-Tehran, M.; Latifi, M.; Shokrgozar, M.A. The influence of surface nanoroughness of electrospun PLGA nanofibrous scaffold on nerve cell adhesion and proliferation. J. Mater. Sci. Mater. Med. 2013, 24, 1551-1560. [CrossRef]

20. Bukala, J.; Buszman, P.P.; Malachowski, J.; Mazurkiewicz, L.; Sybilski, K. Experimental Tests, FEM Constitutive Modeling and Validation of PLGA Bioresorbable Polymer for Stent Applications. Materials 2020, 13, 2003. [CrossRef]

21. Papageorgiou, S.K.; Kouvelos, E.P.; Favvas, E.P.; Sapalidis, A.A.; Romanos, G.E.; Katsaros, F.K. Metal-carboxylate interactions in metal-alginate complexes studied with FTIR spectroscopy. Carbohydr. Res. 2010, 345, 469-473. [CrossRef]

22. Maver, T.; Mohan, T.; Gradisnik, L.; Finsgar, M.; Stana Kleinschek, K.; Maver, U. Polysaccharide Thin Solid Films for Analgesic Drug Delivery and Growth of Human Skin Cells. Front. Chem 2019, 7, 217. [CrossRef]

23. Hinton, T.J.; Jallerat, Q.; Palchesko, R.N.; Park, J.H.; Grodzicki, M.S.; Shue, H.J.; Ramadan, M.H.; Hudson, A.R.; Feinberg, A.W. Three-dimensional printing of complex biological structures by freeform reversible embedding of suspended hydrogels. Sci. Adv. 2015, 1. [CrossRef] [PubMed]

24. Attalla, R.; Puersten, E.; Jain, N.; Selvaganapathy, P.R. 3D bioprinting of heterogeneous bi- and tri-layered hollow channels within gel scaffolds using scalable multi-axial microfluidic extrusion nozzle. Biofabrication 2018, 11, 015012. [CrossRef] [PubMed]

25. Chansoria, P.; Narayanan, L.K.; Schuchard, K.; Shirwaiker, R. Ultrasound-assisted biofabrication and bioprinting of preferentially aligned three-dimensional cellular constructs. Biofabrication 2019, 11, 035015. [CrossRef] [PubMed]

26. Colosi, C.; Shin, S.R.; Manoharan, V.; Massa, S.; Costantini, M.; Barbetta, A.; Dokmeci, M.R.; Dentini, M.; Khademhosseini, A. Microfluidic Bioprinting of Heterogeneous 3D Tissue Constructs Using Low-Viscosity Bioink. Adv. Mater. 2016, 28 , 677-684. [CrossRef]

27. Guo, X.; Wang, Y.; Qin, Y.; Shen, P.; Peng, Q. Structures, properties and application of alginic acid: A review. Int. J. Biol. Macromol. 2020, 162, 618-628. [CrossRef]

28. Muller, M.; Ozturk, E.; Arlov, O.; Gatenholm, P.; Zenobi-Wong, M. Alginate Sulfate-Nanocellulose Bioinks for Cartilage Bioprinting Applications. Ann. Biomed. Eng. 2017, 45, 210-223. [CrossRef]

29. Gershlak, J.R.; Hernandez, S.; Fontana, G.; Perreault, L.R.; Hansen, K.J.; Larson, S.A.; Binder, B.Y.; Dolivo, D.M.; Yang, T.; Dominko, T.; et al. Crossing kingdoms: Using decellularized plants as perfusable tissue engineering scaffolds. Biomaterials 2017, 125, 13-22. [CrossRef]

30. Hickey, R.J.; Modulevsky, D.J.; Cuerrier, C.M.; Pelling, A.E. Customizing the Shape and Microenvironment Biochemistry of Biocompatible Macroscopic Plant-Derived Cellulose Scaffolds. ACS Biomater. Sci. Eng. 2018, 4, 3726-3736. [CrossRef] 
31. Modulevsky, D.J.; Lefebvre, C.; Haase, K.; Al-Rekabi, Z.; Pelling, A.E. Apple derived cellulose scaffolds for 3D mammalian cell culture. PLoS ONE 2014, 9, e97835. [CrossRef] [PubMed]

32. Kono, H.; Onishi, K.; Nakamura, T. Characterization and bisphenol A adsorption capacity of beta-cyclodextrin-carboxymethylcellulosebased hydrogels. Carbohydr. Polym. 2013, 98, 784-792. [CrossRef] [PubMed]

33. Maver, T.; Maver, U.; Mostegel, F.; Griesser, T.; Spirk, S.; Smrke, D.M.; Stana-Kleinschek, K. Cellulose based thin films as a platform for drug release studies to mimick wound dressing materials. Cellulose 2015, 22, 749-761. [CrossRef]

34. Milojevic, M.; Vihar, B.; Banovic, L.; Misko, M.; Gradisnik, L.; Zidaric, T.; Maver, U. Core/shell Printing Scaffolds For Tissue Engineering Of Tubular Structures. J. Vis. Exp. 2019. [CrossRef] [PubMed]

35. Javanbakht, S.; Shaabani, A. Carboxymethyl cellulose-based oral delivery systems. Int. J. Biol. Macromol. 2019, 133, 21-29. [CrossRef]

36. Shingel, K.I. Determination of structural peculiarities of dexran, pullulan and $\gamma$-irradiated pullulan by Fourier-transform IR spectroscopy. Carbohydr. Res. 2002, 337, 1445-1451. [CrossRef]

37. Singh, R.S.; Kaur, N.; Rana, V.; Kennedy, J.F. Pullulan: A novel molecule for biomedical applications. Carbohydr. Polym. 2017, 171, 102-121. [CrossRef]

38. Aschenbrenner, E.; Bley, K.; Koynov, K.; Makowski, M.; Kappl, M.; Landfester, K.; Weiss, C.K. Using the polymeric ouzo effect for the preparation of polysaccharide-based nanoparticles. Langmuir 2013, 29, 8845-8855. [CrossRef]

39. Siddiqui, N.N.; Aman, A.; Silipo, A.; Qader, S.A.; Molinaro, A. Structural analysis and characterization of dextran produced by wild and mutant strains of Leuconostoc mesenteroides. Carbohydr. Polym. 2014, 99, 331-338. [CrossRef]

40. Perez, J.M.; Asati, A.; Nath, S.; Kaittanis, C. Synthesis of biocompatible dextran-coated nanoceria with pH-dependent antioxidant properties. Small 2008, 4, 552-556. [CrossRef]

41. Cadee, J.A.; van Luyn, M.J.; Brouwer, L.A.; Plantinga, J.A.; van Wachem, P.B.; de Groot, C.J.; den Otter, W.; Hennink, W.E. In vivo biocompatibility of dextran-based hydrogels. J. Biomed. Mater. Res. 2000, 50, 397-404. [CrossRef]

42. Tuchilus, C.G.; Nichifor, M.; Mocanu, G.; Stanciu, M.C. Antimicrobial activity of chemically modified dextran derivatives. Carbohydr. Polym. 2017, 161, 181-186. [CrossRef]

43. de Oliveira, S.A.; da Silva, B.C.; Riegel-Vidotti, I.C.; Urbano, A.; de Sousa Faria-Tischer, P.C.; Tischer, C.A. Production and characterization of bacterial cellulose membranes with hyaluronic acid from chicken comb. Int. J. Biol. Macromol. 2017, 97, 642-653. [CrossRef]

44. Alkrad, J.A.; Mrestani, Y.; Stroehl, D.; Wartewig, S.; Neubert, R. Characterization of enzymatically digested hyaluronic acid using NMR, Raman, IR, and UV-Vis spectroscopies. J. Pharm. Biomed. Anal. 2003, 31, 545-550. [CrossRef]

45. Collins, M.N.; Birkinshaw, C. Hyaluronic acid based scaffolds for tissue engineering-A review. Carbohydr. Polym. 2013, 92, 1262-1279. [CrossRef]

46. Gruene, M.; Pflaum, M.; Hess, C.; Diamantouros, S.; Schlie, S.; Deiwick, A.; Koch, L.; Wilhelmi, M.; Jockenhoevel, S.; Haverich, A.; et al. Laser printing of three-dimensional multicellular arrays for studies of cell-cell and cell-environment interactions. Tissue Eng. Part. C Methods 2011, 17, 973-982. [CrossRef]

47. Da Róz, A.L.; Leite, F.L.; Pereiro, L.V.; Nascente, P.A.P.; Zucolotto, V.; Oliveira, O.N.; Carvalho, A.J.F. Adsorption of chitosan on spin-coated cellulose films. Carbohydr. Polym. 2010, 80, 65-70. [CrossRef]

48. Finsgar, M.; Uzunalic, A.P.; Stergar, J.; Gradisnik, L.; Maver, U. Novel chitosan/diclofenac coatings on medical grade stainless steel for hip replacement applications. Sci. Rep. 2016, 6, 26653. [CrossRef]

49. Andrady, A.L.; Torikai, A.; Kobatake, T. Spectral sensitivity of chitosan photodegradation. J. Appl. Polym. Sci. 1996, 62, $1465-1471$. [CrossRef]

50. Kucharska, M.; Butruk, B.; Walenko, K.; Brynk, T.; Ciach, T. Fabrication of in-situ foamed chitosan/ $\beta$-TCP scaffolds for bone tissue engineering application. Mater. Lett. 2012, 85, 124-127. [CrossRef]

51. Croisier, F.; Jérôme, C. Chitosan-based biomaterials for tissue engineering. Eur. Polym. J. 2013, 49, 780-792. [CrossRef]

52. Riaz, T.; Zeeshan, R.; Zarif, F.; Ilyas, K.; Muhammad, N.; Safi, S.Z.; Rahim, A.; Rizvi, S.A.A.; Rehman, I.U. FTIR analysis of natural and synthetic collagen. Appl. Spectrosc. Rev. 2018, 53, 703-746. [CrossRef]

53. Veeruraj, A.; Arumugam, M.; Ajithkumar, T.; Balasubramanian, T. Isolation and characterization of collagen from the outer skin of squid (Doryteuthis singhalensis). Food Hydrocoll. 2015, 43, 708-716. [CrossRef]

54. Belbachir, K.; Noreen, R.; Gouspillou, G.; Petibois, C. Collagen types analysis and differentiation by FTIR spectroscopy. Anal. Bioanal. Chem. 2009, 395, 829-837. [CrossRef]

55. Chevallay, B.; Herbage, D. Collagen-based biomaterials as 3D scaffold for cell cultures: Applications for tissue engineering and gene therapy. Med. Biol. Eng. Comput. 2000, 38, 211-218. [CrossRef]

56. Gauza-Wlodarczyk, M.; Kubisz, L.; Wlodarczyk, D. Amino acid composition in determination of collagen origin and assessment of physical factors effects. Int. J. Biol. Macromol. 2017, 104, 987-991. [CrossRef]

57. Skardal, A.; Mack, D.; Kapetanovic, E.; Atala, A.; Jackson, J.D.; Yoo, J.; Soker, S. Bioprinted amniotic fluid-derived stem cells accelerate healing of large skin wounds. Stem Cells Transl. Med. 2012, 1, 792-802. [CrossRef] [PubMed]

58. Lee, V.K.; Lanzi, A.M.; Ngo, H.; Yoo, S.S.; Vincent, P.A.; Dai, G.H. Generation of Multi-scale Vascular Network System Within 3D Hydrogel Using 3D Bio-printing Technology. Cell. Mol. Bioeng. 2014, 7, 460-472. [CrossRef] [PubMed]

59. Zhang, N.; Liu, X.; Yu, L.; Shanks, R.; Petinaks, E.; Liu, H. Phase composition and interface of starch-gelatin blends studied by synchrotron FTIR micro-spectroscopy. Carbohydr. Polym. 2013, 95, 649-653. [CrossRef] [PubMed] 
60. Hashim, D.M.; Man, Y.B.C.; Norakasha, R.; Shuhaimi, M.; Salmah, Y.; Syahariza, Z.A. Potential use of Fourier transform infrared spectroscopy for differentiation of bovine and porcine gelatins. Food Chem. 2010, 118, 856-860. [CrossRef]

61. Van Vlierberghe, S.; Graulus, G.J.; Keshari Samal, S.; Van Nieuwenhove, I.; Dubruel, P. Porous hydrogel biomedical foam scaffolds for tissue repair. In Biomedical Foams for Tissue Engineering Applications; Woodhead Publishing: Cambridge, UK, 2014 ; pp. 335-390. [CrossRef]

62. Wang, X.; Yan, Y.; Pan, Y.; Xiong, Z.; Liu, H.; Cheng, J.; Liu, F.; Lin, F.; Wu, R.; Zhang, R.; et al. Generation of three-dimensional hepatocyte/gelatin structures with rapid prototyping system. Tissue Eng. 2006, 12, 83-90. [CrossRef]

63. Irvine, S.A.; Agrawal, A.; Lee, B.H.; Chua, H.Y.; Low, K.Y.; Lau, B.C.; Machluf, M.; Venkatraman, S. Printing cell-laden gelatin constructs by free-form fabrication and enzymatic protein crosslinking. Biomed. Microdevices 2015, 17, 16. [CrossRef]

64. Laronda, M.M.; Rutz, A.L.; Xiao, S.; Whelan, K.A.; Duncan, F.E.; Roth, E.W.; Woodruff, T.K.; Shah, R.N. A bioprosthetic ovary created using 3D printed microporous scaffolds restores ovarian function in sterilized mice. Nat. Commun. 2017, 8, 15261. [CrossRef] [PubMed]

65. Litvinov, R.I.; Faizullin, D.A.; Zuev, Y.F.; Weisel, J.W. The alpha-helix to beta-sheet transition in stretched and compressed hydrated fibrin clots. Biophys. J. 2012, 103, 1020-1027. [CrossRef] [PubMed]

66. Watt, K.W.; Takagi, T.; Doolittle, R.F. Amino acid sequence of the beta chain of human fibrinogen: Homology with the gamma chain. Proc. Natl. Acad. Sci. USA 1978, 75, 1731-1735. [CrossRef]

67. Weisel, J.W.; Litvinov, R.I. Fibrin Formation, Structure and Properties. Subcell. Biochem. 2017, 82, 405-456. [CrossRef]

68. Sionkowska, A.; Planecka, A. The influence of UV radiation on silk fibroin. Polym. Degrad. Stab. 2011, 96, 523-528. [CrossRef]

69. Rockwood, D.N.; Preda, R.C.; Yucel, T.; Wang, X.; Lovett, M.L.; Kaplan, D.L. Materials fabrication from Bombyx mori silk fibroin. Nat. Protoc. 2011, 6, 1612-1631. [CrossRef]

70. Voga, M.; Drnovsek, N.; Novak, S.; Majdic, G. Silk fibroin induces chondrogenic differentiation of canine adipose-derived multipotent mesenchymal stromal cells/mesenchymal stem cells. J. Tissue Eng. 2019. [CrossRef]

71. Compaan, A.M.; Christensen, K.; Huang, Y. Inkjet Bioprinting of 3D Silk Fibroin Cellular Constructs Using Sacrificial Alginate. ACS Biomater. Sci. Eng. 2016, 3, 1519-1526. [CrossRef] [PubMed]

72. Zhou, C.Z.; Confalonieri, F.; Jacquet, M.; Perasso, R.; Li, Z.G.; Janin, J. Silk fibroin: Structural implications of a remarkable amino acid sequence. Proteins 2001, 44, 119-122. [CrossRef] [PubMed]

73. Gradisnik, L.; Trapecar, M.; Rupnik, M.S.; Velnar, T. HUIEC, Human intestinal epithelial cell line with differentiated properties: Process of isolation and characterisation. Wien. Klin. Wochenschr. 2015, 127 (Suppl. S5), 204-209. [CrossRef] [PubMed]

74. Stana, J.; Stergar, J.; Gradisnik, L.; Flis, V.; Kargl, R.; Frohlich, E.; Stana Kleinschek, K.; Mohan, T.; Maver, U. Multilayered Polysaccharide Nanofilms for Controlled Delivery of Pentoxifylline and Possible Treatment of Chronic Venous Ulceration. Biomacromolecules 2017, 18, 2732-2746. [CrossRef] [PubMed]

75. Sirghi, L.; Kylián, O.; Gilliland, D.; Ceccone, G.; Rossi, F. Cleaning and Hydrophilization of Atomic Force Microscopy Silicon Probes. J. Phys. Chem. B 2006, 110, 25975-25981. [CrossRef]

76. van Oss, C.J. Surface properties of fibrinogen and fibrin. J. Protein Chem. 1990, 9, 487-491. [CrossRef]

77. Kubiak, K.J.; Wilson, M.C.T.; Mathia, T.G.; Carval, P. Wettability versus roughness of engineering surfaces. Wear 2011, 271, 523-528. [CrossRef]

78. Peniche, C.; Argüelles-Monal, W.; Peniche, H.; Acosta, N. Chitosan: An Attractive Biocompatible Polymer for Microencapsulation. Macromol. Biosci. 2003, 3, 511-520. [CrossRef]

79. Jabaji, Z.; Sears, C.M.; Brinkley, G.J.; Lei, N.Y.; Joshi, V.S.; Wang, J.; Lewis, M.; Stelzner, M.; Martín, M.G.; Dunn, J.C. Use of collagen gel as an alternative extracellular matrix for the in vitro and in vivo growth of murine small intestinal epithelium. Tissue Eng. Part. C Methods 2013, 19, 961-969. [CrossRef]

80. Lovett, M.; Lee, K.; Edwards, A.; Kaplan, D.L. Vascularization Strategies for Tissue Engineering. Tissue Eng. Part. B Rev. 2009, 15, 353-370. [CrossRef]

81. Peng, H.; Poovaiah, N.; Forrester, M.; Cochran, E.; Wang, Q. Ex vivo culture of primary intestinal stem cells in collagen gels and foams. ACS Biomater. Sci. Eng. 2015, 1, 37-42. [CrossRef]

82. Han, J.; Lazarovici, P.; Pomerantz, C.; Chen, X.; Wei, Y.; Lelkes, P.I. Co-electrospun blends of PLGA, gelatin, and elastin as potential nonthrombogenic scaffolds for vascular tissue engineering. Biomacromolecules 2011, 12, 399-408. [CrossRef] [PubMed]

83. Loh, J.W.; Yeoh, G.; Saunders, M.; Lim, L.Y. Uptake and cytotoxicity of chitosan nanoparticles in human liver cells. Toxicol Appl Pharm. 2010, 249, 148-157. [CrossRef] [PubMed]

84. Skardal, A. Perspective: “Universal” bioink technology for advancing extrusion bioprinting-based biomanufacturing. Bioprinting 2018, 10, e00026. [CrossRef]

85. Aydin, L.; Kucuk, S.; Kenar, H. A universal self-eroding sacrificial bioink that enables bioprinting at room temperature. Polym. Adv. Technol. 2020, 31, 1634-1647. [CrossRef]

86. Maver, U.; Gradišnik, L.; Smrke, D.M.; Stana Kleinschek, K.; Maver, T. Impact of growth factors on wound healing in polysaccharide blend thin films. Appl. Surf. Sci. 2019, 489, 485-493. [CrossRef]

87. Maver, T.; Hribernik, S.; Mohan, T.; Smrke, D.M.; Maver, U.; Stana-Kleinschek, K. Functional wound dressing materials with highly tunable drug release properties. RSC Adv. 2015, 5, 77873-77884. [CrossRef] 
88. Milojević, M.; Gradišnik, L.; Stergar, J.; Skelin Klemen, M.; Stožer, A.; Vesenjak, M.; Dobnik Dubrovski, P.; Maver, T.; Mohan, T.; Stana Kleinschek, K.; et al. Development of multifunctional 3D printed bioscaffolds from polysaccharides and NiCu nanoparticles and their application. Appl. Surf. Sci. 2019, 488, 836-852. [CrossRef]

89. Maver, U.; Xhanari, K.; Zizek, M.; Korte, D.; Gradisnik, L.; Franko, M.; Finsgar, M. A combination of interdisciplinary analytical tools for evaluation of multi-layered coatings on medical grade stainless steel for biomedical applications. Eur. J. Pharm. Biopharm. 2018, 128, 230-246. [CrossRef]

90. Mosmann, T. Rapid colorimetric assay for cellular growth and survival: Application to proliferation and cytotoxicity assays. J. Immunol. Methods 1983, 65, 55-63. [CrossRef]

91. Ferrari, M.; Fornasiero, M.C.; Isetta, A.M. MTT colorimetric assay for testing macrophage cytotoxic activity in vitro. J. Immunol. Methods 1990, 131, 165-172. [CrossRef]

92. Van de Loosdrecht, A.; Beelen, R.; Ossenkoppele, g.; Broekhoven, M.; Langenhuijsen, M. A tetrazolium-based colorimetric MTT assay to quantitate human monocyte mediated cytotoxicity against leukemic cells from cell lines and patients with acute myeloid leukemia. J. Immunol. Methods 1994, 174, 311-320. [CrossRef] 